\title{
Blockade of CXCL12/CXCR4 signaling inhibits intrahepatic cholangiocarcinoma progression and metastasis via inactivation of canonical Wnt pathway
}

Shengqiang Zhao, Jing Wang and Chengyong Qin*

\begin{abstract}
Background: Intrahepatic cholangiocarcinoma $(\mathrm{IHCC})$ is the second most frequent primary malignant liver tumor following hepatocellular carcinoma. It is a highly fatal disease and has few therapeutics. The CXC chemokine ligand-12 (CXCL12)/CXC chemokine receptor type 4 (CXCR4) axis has been shown to be involved in tumorgenesis, proliferation, and angiogenesis in a variety of cancers including IHCC. However, its prognostic significance in IHCC is unclear. The purpose of this study was to examine the functional role of CXCR4 in the progression and metastasis of IHCC and explore the underlying mechanism.

Methods: The CXCR4 expression, overall survival, and the clinical characteristics including age, sex, differentiation degree, tumor size, vascular invasion, lymph node metastasis, TNM stage, and T stage were analyzed for $122 \mathrm{IHCC}$ patients. Short hairpin RNA (shRNA) against CXCR4 was used to disrupt the CXCL12/CXCR4 signal transduction pathways in IHCC cell lines. In vitro assays, including CCK-8 assay, flow cytometry, and colony formation assay, and in vivo tumor formation assay were utilized to detect the cell phenotype of CXCR4 knockdown cells. Transwell and wound healing assays were used to examine the IHCC cell invasion and migration ability. The Wnt pathway was assessed by Western blot and $\beta$-Catenin/Tcf transcription reporter assay.
\end{abstract}

Results: We demonstrated that CXCR4 expression was closely correlated with IHCC progression and metastasis characteristics. The overall survival of patients with high CXCR4 expression was significantly lower than that of patients with low CXCR4 expression. Furthermore, we showed that the abrogation of CXCR4 had significantly negative influence on the IHCC cell phenotype, including in vitro cell proliferation, cell cycle, colony formation, cell invasion, and in vivo tumorigenicity. In addition, CXCR4 knockdown downregulated Wht target genes and mesenchymal markers such as Vimentin and Slug.

Conclusions: In conclusion, our result shows that high CXCR4 expression is associated with IHCC progression and metastasis via the canonical Wnt pathway, suggesting that CXCR4 may serve as a promising therapeutic target for IHCC.

Keywords: Intrahepatic cholangiocarcinoma (IHCC), CXC chemokine ligand-12 (CXCL12)/chemokine receptor type 4 (CXCR4), Prognosis, Metastasis, Wnt pathway

\footnotetext{
* Correspondence: chengyong.qin@yahoo.com

Department of Gastroenterology, Shandong Provincial Hospital, Shandong University, Jinan, China
}

\section{Ciomed Central}

(c) 2014 Zhao et al.; licensee BioMed Central Ltd. This is an Open Access article distributed under the terms of the Creative Commons Attribution License (http://creativecommons.org/licenses/by/4.0), which permits unrestricted use, distribution, and reproduction in any medium, provided the original work is properly credited. The Creative Commons Public Domain Dedication waiver (http://creativecommons.org/publicdomain/zero/1.0/) applies to the data made available in this article unless otherwise stated. 


\section{Background}

Intrahepatic cholangiocarcinoma (IHCC) is a malignancy whose pathogenesis involves abnormal biliary epithelial differentiation [1]. It is the most frequent primary malignant liver tumor next to hepatocellular carcinoma and is highly fatal because of its early invasion, widespread metastasis, and the lack of an effective therapy [2,3]. Therefore, it is urgent to uncover the molecular mechanisms of IHCC and identify potential therapeutic targets to improve the treatment. Chemokine receptors form a large family of proteins that mediate chemotaxis of cells towards a gradient of chemokines. Many studies have shown that chemokines and their receptors are implicated in the development of different types of cancers [4-6]. One of the best studied chemokine receptors is CXCR4. CXCR4 is a $\mathrm{G}$ protein-coupled chemokine receptor, encoded on chromosome 2 [7]. During embryonic development, CXCR4 is expressed on progenitor cells, allowing the migration from their birthplace to their final destination where they will differentiate into organs and tissues. In the late 1990s, CXCR4 expressed on CD4+ T cells was found to serve as a co-entry receptor for human immunodeficiency virus HIV-1 [8]. The following-up studies also found that CXCR4 can mediate the metastasis of a variety of cancers $[4,6,9,10]$. CXCR4 selectively binds the CXC chemokine ligand-12 (CXCL12, or SDF-1), which has been found to be important in the tumorigenesis, proliferation, metastasis, and angiogenesis in cancers $[11,12]$. CXCR4 has been reported to be upregulated in more than 20 cancers, including ovarian [13], prostate [14], esophageal [15], melanoma [16], neuroblastoma [17], and renal cell carcinoma [18], and plays an important role in the communication of cancer cells with their microenvironment $[19,20]$. Moreover, CXCR4-positive cancer cells can migrate toward distant organs in response to CXCL12 gradient. By inhibition of CXCR4, the growth and invasion of cancer cells can be impaired [21-23]. In 2014, T. Yu et al. [24] found that suppressing expression of CXCR4 by MicroRNA-9 could inhibit the proliferation of oral squamous cell carcinoma cells both in vitro and in vivo through the Wnt/ $\beta$-catenin signaling pathway, and activation of CXCR4 expression led to the constitutive activation of $\beta$-catenin, implying the important role of $\mathrm{Wnt} / \beta$-catenin in CXCR4 signaling, which was consistent with the previous reports in colorectal cancer [25], ovarian cancer [26], pancreatic cancer [23], and bone marrow stromal cells [27].

In cholangiocarcinoma, Ohira et al. [28] demonstrated that CXCR4 was mainly expressed in IHCC cells and CXCL12 in stromal fibroblasts, and the interaction of CXCL12 released from fibroblasts and CXCR4 expressed on IHCC cells may be actively involved in IHCC migration, suggesting CXCR4 could be a therapeutic target to prevent IHCC invasion. This possibility was confirmed by Gentilini et al. [29] using AMD3100, a non-peptide antagonist of the
CXCR4, and Tan et al. [30] using siRNA targeting at CXCR4. In 2012, CXCL12/CXCR4 was further reported to mediate angiotensin II-enhanced epithelial-to-mesenchymal transition (EMT) in IHCC [31]. More recently, Leelawat K. et al. [4] found that CD24 could induce CXCR4 expression in cholangiocarcimoma cells, which may assist invasion of the cancer cells. When treated by AMD3100, the motility and invasiveness of CD24 (+) cells were decreased, implying the importance of CXCR4 in cholangiocarcinoma cell invasion. However, the precise function of CXCR4 and the signal transduction pathways following CXCR4 activation in IHCC remain elusive. The aim of this study was to define the role of CXCR4 in IHCC and elucidate the underlying mechanism.

\section{Methods}

\section{Cell culture}

Human intrahepatic cholangiocarcinoma cell lines, $\mathrm{HuC}$ CT1 (ATCC, Manassas, VA, USA), HCCC-9810 ( Keygen Biotech, China), RBE ( Keygen Biotech, China), and Huh28 (Keygen Biotech, China) were cultured at $37^{\circ} \mathrm{C}$ in RPMI 1640 medium (Hyclone) supplemented with $10 \%$ fetal calf serum, $100 \mathrm{U} / \mathrm{ml}$ penicillin, and $100 \mathrm{mg} / \mathrm{ml}$ streptomycin in humidified atmosphere containing $5 \% \mathrm{CO}_{2}$.

\section{Immunohistochemistry}

Samples including 122 primary IHCCs, 75 matched metastatic lymph nodes, and 122 adjacent non-cancerous liver tissues containing normal intrahepatic bile ducts (at least $5 \mathrm{~cm}$ distant from the tumor edge) were obtained from the Department of Pathology, Shandong Provincial Hospital. Immunohistochemical staining for CXCR4 was performed using the SABC kit (Boster, Wuhan, China) according to the manufacturer's instruction. Primary antibody for CXCR4 (1:50, polyclonal, Abcam, MA, USA) was used for overnight incubation at $4{ }^{\circ} \mathrm{C}$. For the evaluation of CXCR4 IHC staining, a semi-quantitative scoring criterion was used, in which both the staining intensity and positive areas were recorded. A staining index (values $0-12$ ), obtained as the intensity of CXCR4-positive staining (weak, 1 ; moderate, 2; strong, 3 ) and the proportion of immunepositive cells of interest $(0 \%, 0 ;<10 \%, 1 ; 10-50 \%, 2 ; 51-$ $80 \%, 3 ;>80 \%, 4)$, were calculated. The cases were grouped into low (score 0-6) and high (scores 8-12) CXCR4 expression. The study was approved by the Ethics Committee of Shandong Provincial Hospital Affiliated to Shandong University, as stipulated by the Declaration of Helsinki, with written informed consent for the use of the specimens from all enrolled patients.

\section{Construction and transfection of CXCR4 shRNAs}

This study utilized three CXCR4 shRNA targeting different regions of the CXCR4 [GenBank: NM_003467]. The shCXCR4-1 targeted CXCR4 mRNA at nucleotides 1093- 
1111 with sense: 5' - AGCGAGGTGGAC ATTCATC-3', and antisense: 5'- GATGAATGTCCACCTCGCT -3'; The shCXCR4-2 targeted CXCR4 mRNA at nucleotides 741759 with sense: $5^{\prime}$ - CTGTCCTGCTATTGCATTA - ${ }^{\prime}$ ', and antisense: 5' - TGACAGGACGACGATAACGTAAT -3'; The shCXCR4-3 was designed to be homologous to nucleotides 206-224 of the human CXCR4 with sense: 5'-TGAGAAGCATGACGGACAA-3', antisense: 5'-TTGTCCGT CATGCTTCTCA-3' [23]. A negative control, targeting at no region in human genome, was designed with sense: $5^{\prime}$ TTCTCCGAACGTGTCACGT-3', antisense: 5' -ACGTGA CACGTTCGGAGAA-3'. These shRNA oligos were cloned to lentiviral vector pLKO.1 following the instruction provided by Addgene (Boston, MA, USA). All constructs were verified by sequencing. Stable transfections were performed using Lipofectamine 2000 (Invitrogen, Carlsbad, CA, USA) according to the manufacturer's instructions.

\section{Quantitative real-time RT-PCR}

RNA was isolated from cells and reverse-transcribed. Real-time RT-PCR Primers specific for target genes were as follows: CXCR4, forward 5'-GATCAGCATCGACT CCTTCA-3' and reverse $5^{\prime}$-GGCTCCAAGGAAAGC ATAGA-3'; $\beta$-catenin, forward 5'-AAAATGGCAGTGC GTTTAG-3' and reverse 5'-TTTGAAGGCAGTCTGT CGTA-3'; c-myc, forward 5' -AATGAAAAGGCCCCCAA GGTAGTTATCC-3' and reverse 5'-GTCGTTTCCGCA ACAAGTCCTCTTC-3'; CD44, forward 5'-AGAAGGTG TGGGCAGAAGAA- 3 ' and reverse $5^{\prime}$-AAATGCACCAT TTCCTGAGA-3'; Vimentin, forward 5'-TGTCCAAA TCGATGTGGATGTTTC- $3^{\prime}$ and reverse $5^{\prime}$-TTGTAC CATTCTTCTGCCTCCTG-3'; Slug, forward 5'-TGTT GCAGTGAGGGCAAGAA-3' and reverse 5'-GACCCT GGTTGCTTCAAGGA-3'. GAPDH (forward: 5'-AACG GGAAGCTTGTCATCAATGGAAA-3', reverse: 5' -GCA TCAGCAGAGGGGGCAGAG-3') served as an internal control. Experiments were repeated three times in duplicates. Relative gene expression was calculated using the $2^{-\Delta \Delta \mathrm{ct}}$ method.

\section{Cell proliferation and cell cycle assays}

Cell proliferation was measured using a Cell Counting Kit8 (CCK-8) (Dojindo Molecular Technologies, Kumamoto, Japan). Control cells or cells stably transfected with shCXCR4 or negative control were seeded into 96-well plates at 2000 cells per well and incubated overnight with or without CXCL12 (R\&D, MN, USA) at $100 \mathrm{ng} / \mathrm{ml}$. Viability of cells were measured using a Cell Counting Kit-8. Briefly, $10 \mu \mathrm{l}$ of CCK-8 solution was added to each well after 1,2 , 3,4 and 5 days for proliferation measurement, respectively. In viable cells, WST-8 was metabolized producing a chromogen that was detected at $450 \mathrm{~nm}$ using a Spectra Max M2 spectrophotometer (Molecular Devices, Sunnyvale, California, USA).
For cell cycle analysis, transfected cells were cultured for $24 \mathrm{~h}$, collected, fixed into $70 \%$ ethanol at $-20^{\circ} \mathrm{C}$ for $24 \mathrm{~h}$, stained with $50 \mu \mathrm{g} / \mathrm{ml}$ propidium iodide (Kaiji, Nanjing, China) and analyzed with a FACS Calibur (Epics XL-4; Beckman Coulter, Brea, California, USA).

\section{Colony formation assay}

A quantity of 500 cells transfected with either shCXCR4 or negative control were cultured in 6-well plates with or without CXCL12 for 2 weeks in regular culture medium. Colonies with more than 50 cells per colony were counted, fixed with methanol for $15 \mathrm{~min}$, and stained with hematoxylin and eosin $(\mathrm{H} \& \mathrm{E})$. All the experiments were performed in triplicate wells and repeated at least three times.

\section{$\beta$-Catenin/Tcf transcription reporter assay}

Briefly, $1 \times 10^{5}$ cells were seeded each well in a 24-well plate before transfection with the construct of TOPflash or FOPflash reporter plasmid (Millipore, Billerica, MA, USA). TOPflash comprised three copies of the Tcf/Lef sites upstream of a thymidine kinase (TK) promoter and the Firefly luciferase gene. FOPflash comprised three mutated copies of Tcf/Lef sites and was used as a control for measuring nonspecific activation of the reporter. All transfections were performed using $0.8 \mu \mathrm{g}$ of TOPflash or FOPflash plasmid and $2 \mu \mathrm{l}$ of Lipofectamine 2000. To normalize the transfection efficiency in reporter assays, the cells were co-transfected with $0.02 \mu \mathrm{g}$ of an internal control reporter plasmid, containing Renilla reniformis luciferase driven by the TK promoter. Twenty four hours after transfection, the luciferase assay was performed with the Dual Luciferase Assay System kit (Promega Corp., Madison, WI, USA). Relative luciferase activity was reported as the fold induction after normalization for transfection efficiency.

\section{Wound healing and matrigel invasion assays}

Cells transfected with negative control or shCXCR4 were seeded in 6-well plates and cultured. Upon reaching appropriate confluence, cells were serum starved for $24 \mathrm{~h}$, and then the cell layer was scratched with a sterile plastic tip, immediately washed twice with PBS, and cultured in serum free 1640 medium with or without CXCL12 at $37^{\circ} \mathrm{C}$ in a humidified incubator with $5 \% \mathrm{CO}_{2}$. At $24 \mathrm{~h}$, the plates were photographed under a microscope.

For invasion assay, cells were re-suspended in serumfree medium and seeded in the top chambers of Matrigelcoated (invasion) chambers (24-well insert, $8 \mu \mathrm{m}$ pore, Corning Costar Corp., Cambridge, MA, USA) at the concentration of $2 \times 10^{5}$ per $200 \mu \mathrm{l}$ medium. The lower chambers were filled with $0.5 \mathrm{ml}$ of normal culture medium with or without CXCL12 $(100 \mathrm{ng} / \mathrm{ml})$. After $24 \mathrm{~h}$, the cells on the upper surface of the membrane were removed 
using cotton tips, and cells that migrated to the lower surface were fixed in $4 \%$ paraformaldehyde for $15 \mathrm{~min}$ at room temperature, stained with hematoxylin and eosin $(\mathrm{H} \& \mathrm{E})$, and counted under the light microscopy.

\section{Western blotting}

Whole cell extracts were prepared in lysis buffer as described previously [32]. The cell lysates were separated by electrophoresis in 10\% SDS-polyacrylamide gels, transferred to nitrocellulose membranes, blocked in 5\% nonfat milk, and incubated with primary antibodies against CXCR4 (1:1000 dilution, Abcam), phospho-CXCR4 (1:1000 dilution, Abcam), $\beta$-catenin (1:1000 dilution, Abcam), Vimentin
(1:1000 dilution, Abcam), MMP-9 (1:1000 dilution, Abcam), and $\beta$-actin (1:5000 dilution; Abcam) at $4{ }^{\circ} \mathrm{C}$ overnight. After incubation with corresponding peroxidase-conjugated secondary antibodies (1:5000 dilution, Abcam), protein bands were detected using an enhanced chemiluminescence reagent (Sigma, Ronkonkoma, New York, USA).

\section{Tumorigenicity assay in nude mice}

Five to six-week-old male nude mice used in the studies were purchased from the Institute of Zoology, Chinese Academy of Sciences (Beijing, China). After 4 days of acclimatization, a total of $2 \times 10^{6}$ IHCC cells stably transfected with either sh-CXCR4 or negative control were

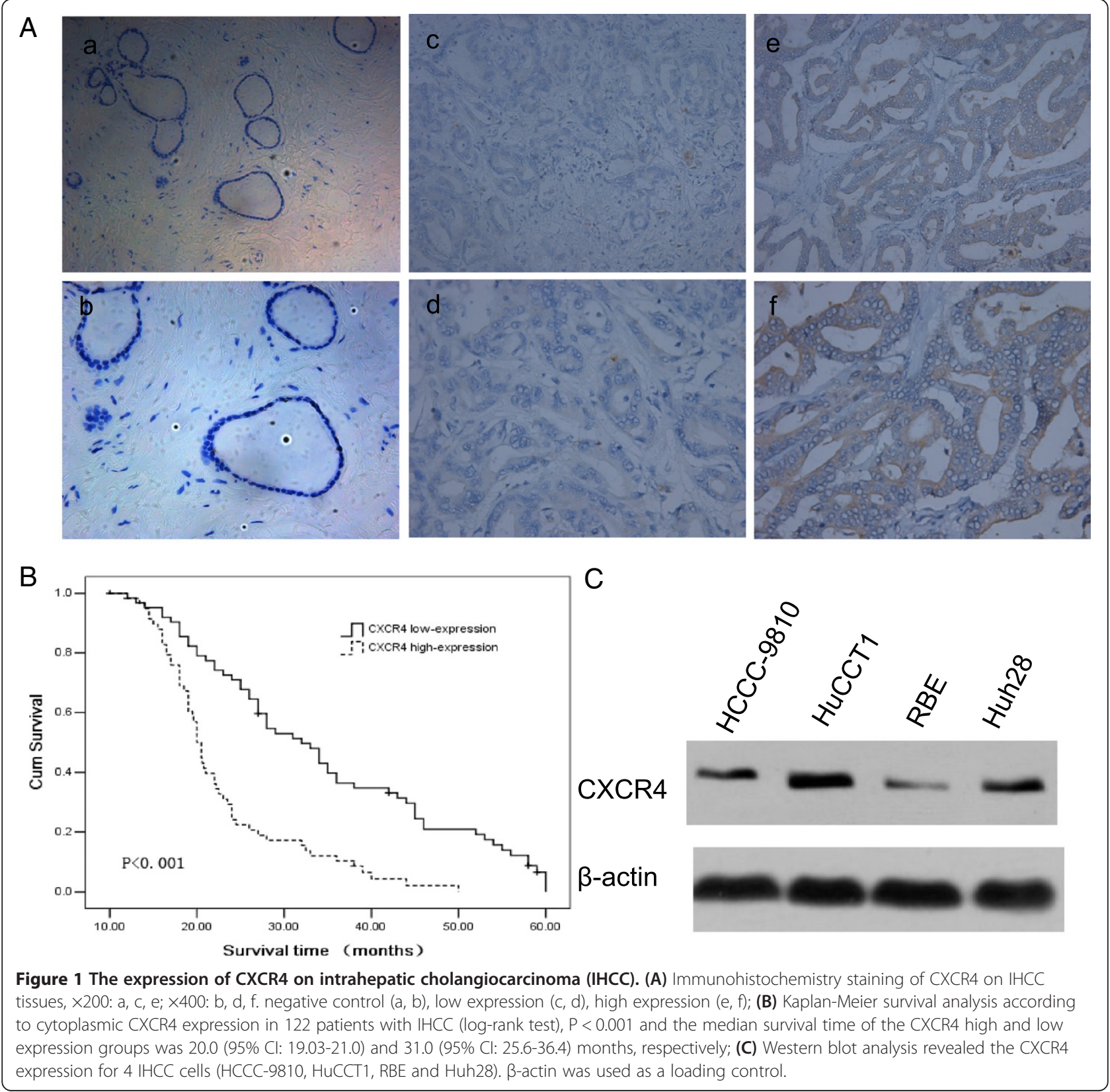


injected subcutaneously into either side of the groin of each mouse (left: negative control cell, right: sh-CXCR4 for group A, and inversely for group B). Each group contained 3 mice. The mice were killed on the 28th day after injection. The mice were manipulated according to the guidelines approved by the Shandong University Institutional Animal Care and Use Committee (IACUC).

\section{Statistical analysis}

The data are presented as percentages of control \pm SEM or means \pm SEM from multiple experiments. The statistical significance between groups was determined using the Student's t-test. Overall survival was counted from the first day of surgery to the date of death or the last followup visit and the estimated value was calculated by the Kaplan-Meier method and compared between groups via the log-rank test. SPSS version 12 (SPSS Inc. Chicago, IL, USA) software was used for all data analyses.

\section{Results}

Association of CXCR4 expression level with IHCC cancers Immunohistochemistry staining results showed that CXCR4 expression was detected in the cytoplasm of most IHCC cells but not in the adjacent non-tumorous tissues. The representative results are shown in Figure 1A. A total of 122 IHCC cancer patients (60 with high CXCR4 expression and 62 with low CXCR4 expression) were included in the analysis. The demographic distributions are shown in Table 1. CXCR4 expression distribution was not significantly different in age, sex, differentiation degree, and tumor size groups. However, there were more high CXCR4 expression samples among patients with vascular invasion or lymph node metastasis (63.6 and $66.7 \%$, respectively) than in the non-vascular invasion or lymph node metastasis groups (32.1 and 21.3\%; $\mathrm{P}=0.001$ and $\mathrm{P}<0.001$ for the two groups, respectively). Moreover, the proportion of high CXCR4 expression samples increased with the increased TNM stages from $13.6 \%$ in I/II stage to $72.1 \%$ in IV group $(\mathrm{P}<0.001)$. In addition, the distribution of $\mathrm{T}$ stage showed that the percentage of high expression tumors rose significantly with increasing $\mathrm{T}$ stage $(\mathrm{P}<0.001)$. Table 2 shows that there was no difference in the CXCR4 expression between primary IHCC and metastasized lymph nodes, implying CXCR4 expression was not affected by the different microenvironment in these sites. These data indicated that CXCR4 expression was significantly correlated with vascular invasion, lymph node metastasis, and the tumor node metastasis stages, all of which are characteristics of tumor progression and metastasis. In addition, a Kaplan-Meier analysis showed that CXCR4 was a powerful prognostic factor for overall survival $(\mathrm{P}<0.001)$ and the median survival time of the high, low CXCR4 expression groups was 20.0 (95\% CI: 19.03-21.0) and 31.0 (95\% CI: 25.6-36.4) months, respectively (Figure 1B). In vitro, CXCR4 expression was
Table 1 Relationship between expression of CXCR4 and clinicopathological features in IHCC

\begin{tabular}{|c|c|c|c|c|c|c|c|}
\hline & \multicolumn{5}{|c|}{ CXCR4 } & \multirow[t]{3}{*}{$x^{2}$} & \multirow[t]{3}{*}{$P$ value } \\
\hline & \multirow{2}{*}{$\frac{\text { Case }}{\mathrm{n}}$} & \multicolumn{2}{|c|}{ High } & \multicolumn{2}{|c|}{ Low } & & \\
\hline & & $n$ & $\%$ & $n$ & $\%$ & & \\
\hline Total & 122 & 60 & 50.8 & 62 & 49.2 & & \\
\hline Sex & & & & & & 0.688 & 0.447 \\
\hline Male & 81 & 42 & 51.9 & 39 & 48.1 & & \\
\hline Female & 41 & 18 & 43.9 & 23 & 56.1 & & \\
\hline Age & & & & & & 1.625 & 0.254 \\
\hline$\geq 60$ & 80 & 36 & 45 & 44 & 55 & & \\
\hline$<60$ & 42 & 24 & 57.1 & 18 & 42.9 & & \\
\hline Degree of Differentiation & & & & & & 3.673 & 0.155 \\
\hline Well & 16 & 5 & 31.3 & 11 & 68.7 & & \\
\hline Moderate & 69 & 33 & 47.8 & 36 & 52.2 & & \\
\hline Poorly & 37 & 22 & 59.4 & 15 & 40.6 & & \\
\hline Tumor size & & & & & & 0.265 & 0.709 \\
\hline$<=4.0 \mathrm{~cm}$ & 46 & 24 & 52.1 & 22 & 47.9 & & \\
\hline$>4.0 \mathrm{~cm}$ & 76 & 36 & 47.4 & 40 & 52.6 & & \\
\hline Vascular invasion & & & & & & 12.022 & 0.001 \\
\hline Present & 66 & 42 & 63.6 & 24 & 36.4 & & \\
\hline Absent & 56 & 18 & 32.1 & 38 & 67.9 & & \\
\hline CA199 & & & & & & 6.664 & 0.011 \\
\hline$\leq 35 \mathrm{KU} / \mathrm{L}$ & 53 & 19 & 34.6 & 34 & 65.4 & & \\
\hline$>35 \mathrm{KU} / \mathrm{L}$ & 69 & 41 & 60 & 28 & 40 & & \\
\hline Lymph node metastasis & & & & & & 25.231 & $<0.001$ \\
\hline No & 47 & 10 & 21.3 & 37 & 78.7 & & \\
\hline Yes & 75 & 50 & 66.7 & 25 & 33.3 & & \\
\hline TNM stage & & & & & & 20.443 & $<0.001$ \\
\hline | and || & 22 & 3 & 13.6 & 19 & 86.4 & & \\
\hline III & 57 & 26 & 45.6 & 31 & 54.4 & & \\
\hline IV & 43 & 31 & 72.1 & 12 & 27.9 & & \\
\hline T stage & & & & & & 15.937 & $<0.001$ \\
\hline $\mathrm{T} 1-\mathrm{T} 2$ & 48 & 17 & 35.4 & 31 & 64.6 & & \\
\hline $\mathrm{T} 3$ & 34 & 13 & 32.4 & 21 & 67.6 & & \\
\hline T4 & 40 & 30 & 75 & 10 & 25 & & \\
\hline
\end{tabular}

detected in all four IHCC cell lines and the HuCCT-1 cell line had the highest expression, which was therefore used in the experiments described in this study (Figure 1C).

\section{The establishment of shCXCR4}

Knockdown of transcripts using shRNA is a powerful tool to study gene function. To study the long-term growth pattern of IHCC cells in vitro, we constructed lentishCXCR4-1, -shCXCR4-2, -shCXCR4-3 and -shCXCR4NC (negative control vector). QT-PCR analysis showed 
Table 2 Expression of CXCR4 in human intrahepatic cholangiocarcinomas and lymph node metastasis

\begin{tabular}{|c|c|c|c|c|}
\hline & \multirow[t]{3}{*}{ Case $\mathbf{n}$} & \multicolumn{2}{|c|}{ CXCR4 expression } & \multirow[t]{3}{*}{$P$ value } \\
\hline & & High & Low & \\
\hline & & n (\%) & n (\%) & \\
\hline Primary intrahepatic cholangiocarcinomas & 122 & & & \\
\hline With nodal metastases & 75 & $50(66.7)$ & 25(33.3) & $<0.001$ \\
\hline Without nodal metastasis & 47 & $10(21.3)$ & $37(78.7)$ & \\
\hline \multicolumn{5}{|l|}{ Intrahepatic carcinomas with nodal metastasis } \\
\hline Primary IHCC & 75 & $50(66.7)$ & 25(33.3) & 0.038 \\
\hline Matched lymph node metastases & 75 & $62(82.7)$ & 13(17.3) & \\
\hline
\end{tabular}

that compared with lenti-shCXCR4-NC cells, the CXCR4 mRNA expression was inhibited up to $70 \%$ in lentishCXCR4-2 and -3-transfected cell lines, particularly in lenti-shCXCR4-3 cells $(\mathrm{P}<0.001)$, which was employed in the following experiments (Figure 2A). Moreover, the CXCR4 protein level was also downregulated significantly in lenti-shCXCR4 compared with lentishCXCR4-NC cells (Figure 2B). Notably, the decrease of
CXCR4 phosphorylation at serine 339 was observed in lenti-shCXCR4 cells (Figure 2C).

Abrogation of CXCR4 inhibits in vitro IHCC cell proliferation, cell cycle, and colony-forming ability, and in vivo tumorigenicity

To confirm the inhibitory effect of CXCR4 on cell growth, cells stably transfected with lenti-shCXCR4-3 or lenti-
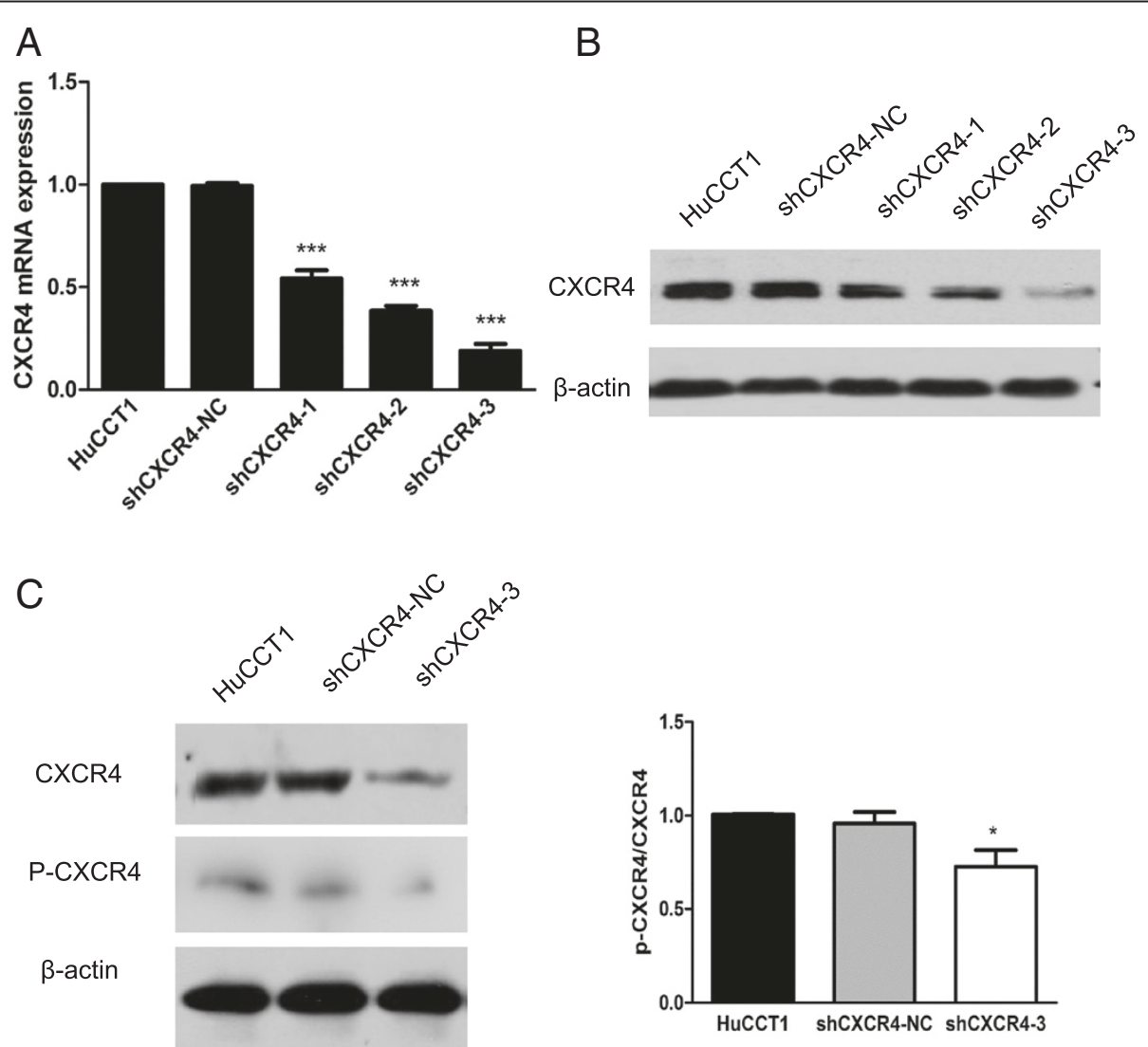

Figure 2 Establishment of stable CXCR4 knockdown. (A) QT-PCR analysis of CXCR4 expression after the transfection of different CXCR4 shRNA expression vectors: shCXCR4-1, shCXCR4-2, shCXCR4-3, shCXCR4-NC (negative control) and HuCCT1, ${ }^{* * *} \mathrm{P}<0.001$ compared with shCXCR4-NC cells; (B) Western blot with CXCR4 antibody of different transfected IHCC cells. $\beta$-actin was used as a loading control; (C) Western blot showed the different expressions2 of CXCR4 and phosphorylated CXCR4 on Serine 339 (P339-CXCR4), together with the $P$-CXCR4/total CXCR4 ratio (*P $<0.05)$ on transfected cells. $\beta$-actin was used as a loading control. 
shCXCR4-NC were cultured. CCK-8 assay showed that shCXCR4-3 cells grew slower than shCXCR4-NC cells. Upon treatment by the CXCR4 ligand CXCL12, IHCC cell growth was accelerated. The difference was significant on day $4(\mathrm{P}<0.05)$ and day $5(\mathrm{P}<0.01)$. However, there was no difference between HuCCT-1 cells and shCXCR4-NC cells (Figure 3A). Analysis of cell cycle distribution by flow cytometry demonstrated a prolonged and prominent delay in progression from G0 to G1 phase (48.9 vs $74.8 \%$ ) together with a reduction at both S phase (48.4 vs $24.7 \%)$ and $\mathrm{G} 2-\mathrm{M}$ phase (2.68 vs $0.49 \%)$. To explore the effect of CXCR4 knockdown on tumorigenesis in vitro, we
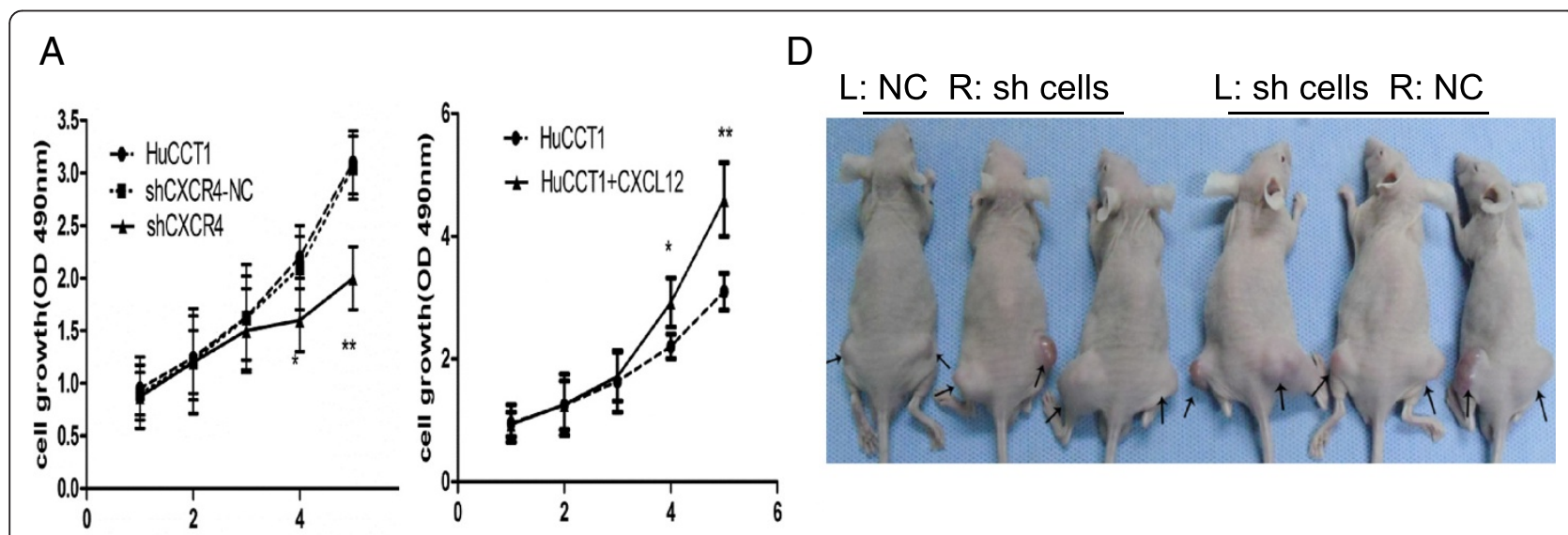

B
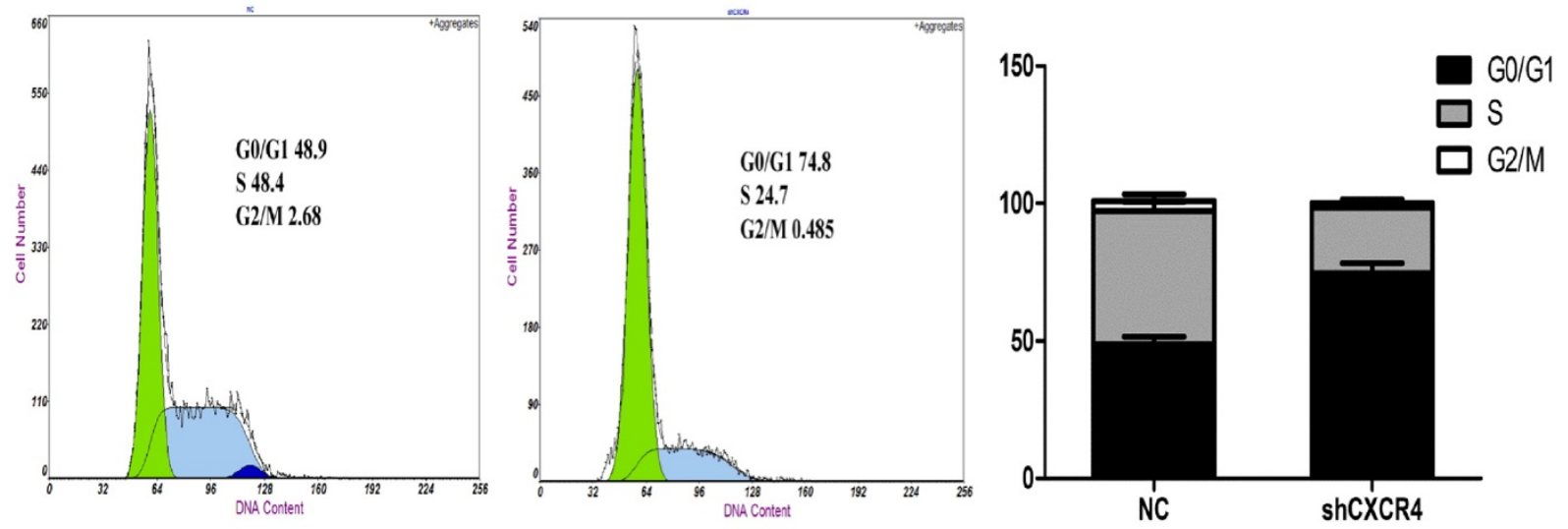

C

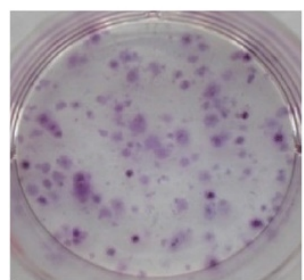

NC

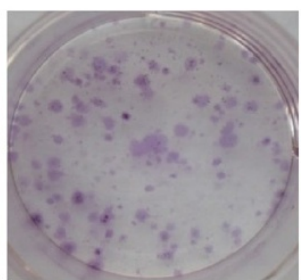

shCXCR4

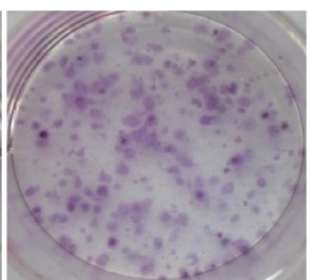

$\mathrm{NC}+\mathrm{CXCL} 12$

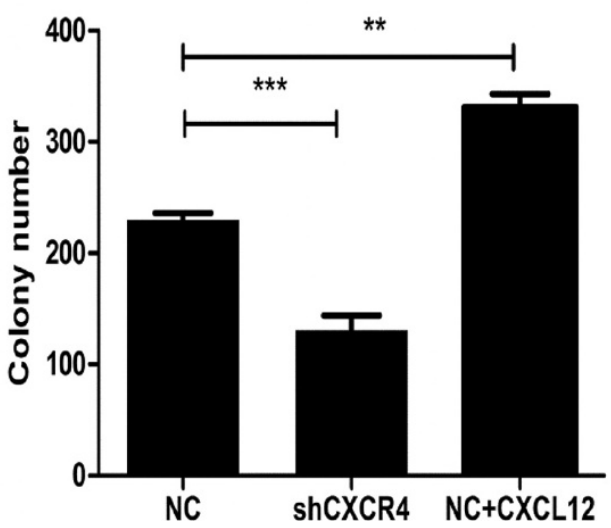

Figure 3 The influence of CXCR4 knockdown on the cell phenotype. (A) CCK-8 assay was analyzed for shCXCR4, shCXCR4-NC, HuCCT1 and CXCL12 (100 ng/ml) stimulated shCXCR4-NC on days 1, 2, 3, 4, and 5; (B) Distribution of cell cycle phases was demonstrated by flow cytometric analysis of shCXCR4 and shCXCR4-NC cells; (C) Colony assay was assessed to evaluate the cell colony formation ability. The count number of the colony was shown in the diagram; (D) The tumor formation ability of shCXCR4 and shCXCR4-NC cells in vivo. ${ }^{*} P<0.05,{ }^{* *} P<0.01,{ }^{* * * P}<0.001$ compared with shCXCR4-NC cells. 
performed colony formation assay. The data showed that shCXCR4-3 decreased the colony formation of IHCC cells $(\mathrm{P}<0.01)$, while CXCR4 ligand CXCL12 increased it $(\mathrm{P}<$ 0.001) (Figure 3C). To explore the effect of CXCR4 knockdown on tumorigenesis in vivo, shCXCR4-3 and shCXCR4-NC cells were injected into either side of $\mathrm{BALB} / \mathrm{c}$ nude mice subcutaneously. As shown in Figure 3D, shCXCR4-3 inhibited the tumor formation of IHCC cells in vivo.

CXCR4 knockdown inhibits Wnt activity, Wnt downstream genes, and the invasion-related genes

As an important pathway for gastrointestinal cancer development, the Wnt/ $\beta$-catenin pathway and tumor invasionassociated genes have attracted great attention. The $\beta$-catenin/Tcf transcription reporter assay has been recognized as an important method for assessing Wnt pathway activity. Because TOPflash has three TCF-binding sites, it can be applied to measure the activation of the canonical Wnt pathway. Our data showed that compared with the shCXCR4-NC cells, the CXCR4 knockdown cells exhibited decreased TOPflash activity $(\mathrm{P}<0.01)$ with FOPflash activity unchanged. Activation of CXCR4 with its ligand, CXCL12 enhanced TOPflash activity significantly $(\mathrm{P}<0.01)$ but had no impact on FOPflash activity (Figure 4A). Moreover, QTPCR analysis showed that Wnt target genes such as $\beta$ catenin, c-myc, and CD44 were decreased in shCXCR4-3 cells but increased when activated by CXCL12 (Figure 4B). Meanwhile, the inhibition of CXCR4 resulted in decreased expression of invasion-related genes Slug, Vimentin and MMP-9 and activation of CXCR4 increased the expression of these genes (Figure $4 \mathrm{~B}$ and $\mathrm{C}$ ). These findings suggested that the inhibitory effect of CXCR4 in IHCC cells was mediated, at least partially, through the canonical Wnt pathway.

\section{CXCR4 knockdown decreases the invasion and migration of IHCC cancer cells}

To determine the effect of CXCR4 on cancer cell invasion and migration, Matrigel invasion and wound healing assays were performed. Representative staining results are shown in Figure 5. The data demonstrated that compared with the control cells, the migration and invasion ability of shCXCR4-transfected cancer cells were inhibited $(\mathrm{P}<$ 0.001) and when activated by CXCL12, shCXCR4 cells still showed a less obvious increase in both invasion and
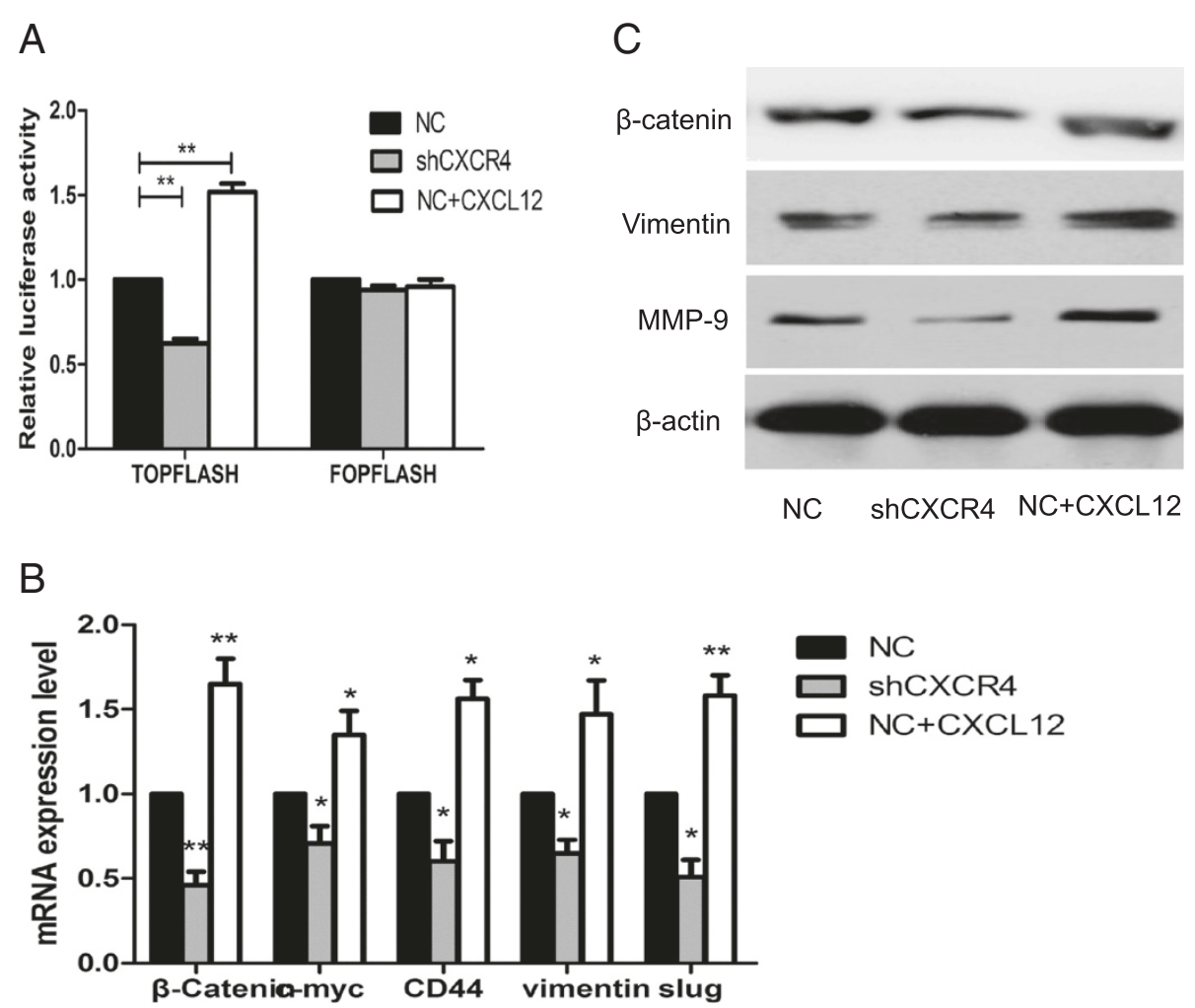

Figure 4 The influence of CXCR4 knockdown on Wnt target genes and invasion-related genes. (A) The $\beta$-Catenin/Tcf transcription reporter assay. Normalized with control reporter plasmid, the relative luciferase activity was demonstrated. ${ }^{* *} \mathrm{P}<0.01$ compared with NC cells; (B) QT-PCR was applied to examine the change of Wnt downstream target genes expression including $\beta$-catenin, c-myc, CD44, Vimentin and Slug by the $2^{-\Delta C \mathrm{Ct}}$ method. shCXCR4 inhibited the expression of these genes, while CXCL12 enhanced their expression. ${ }^{*} \mathrm{P}<0.05$, ${ }^{* *} \mathrm{P}<0.01$ compared with NC cells; (C) Western blot analysis was used to detect $\beta$-catenin, Vimentin and MMP-9 protein expression. $\beta$-actin was used as a loading control. 

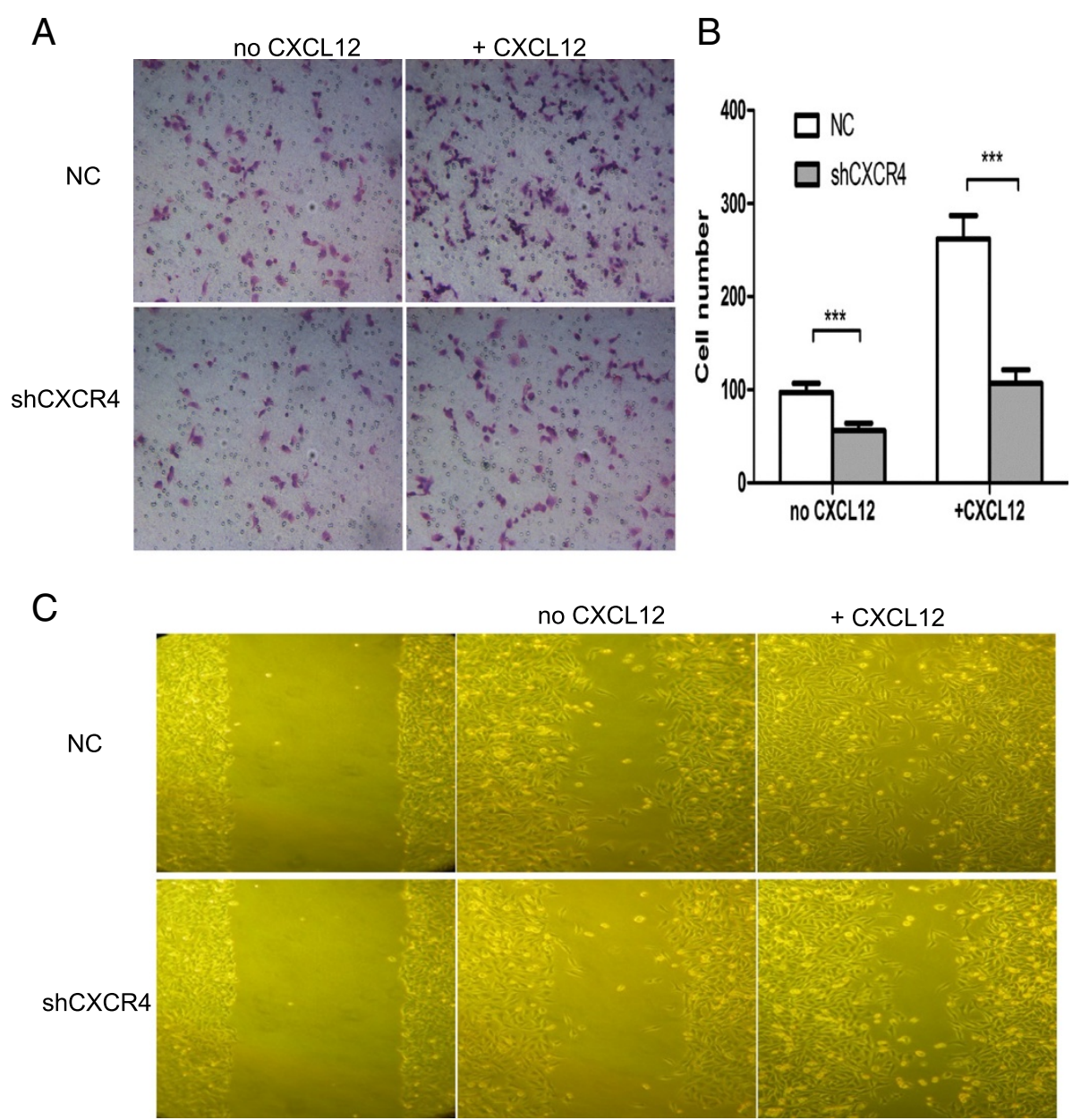

Figure 5 The abrogation of CXCR4 inhibits the invasion and migration ability of IHCC cells. (A) Representative staining figures: shCXCR4 and negative control invading cells with and without CXCL12 stimulation $(100 \mathrm{ng} / \mathrm{ml}) ;(\mathbf{B})$ the diagram of the count analysis, ${ }^{* * *}$ P $<0.001$ compared with NC cells; (C) Wound healing assay of shCXCR4 and negative control cells with or without CXCL12 stimulation (100 ng/ml).

migration $(\mathrm{P}<0.001)$, showing the essential role of CXCR4 in IHCC cell migration and invasion, even in CXCL12 activated cancer cells.

\section{Discussion}

Compared with other malignancies, IHCC is generally characterized by strong proliferation, invasion, and early metastasis. Many factors such as adhesion molecules, proteases, cytokines, and chemokine are involved in these processes. CXCR4 and CXCL12 play an essential role in tumor growth, metastasis, and cancer cell-microenvironment interaction. CXCR4 has been known to be overexpressed in more than 20 human tumor types [13-18], and CXCR4 antagonists inhibit tumor growth in multiple experimental orthotopic $[33,34]$, subcutaneous human xenografts [35,36], and transgenic mouse models [37]. Preclinical cancer models have revealed that directed metastasis of cancer cells is mediated by CXCR4 activation and migration of cancer cells is towards CXCL12 expressing organs $[14,35,38]$ while targeting
CXCR4 impairs the spread of cancer cells and development of metastasis [34,37,38]. Moreover, high levels of CXCL12 expressed by cancer cells and tumor-associated stromal cells directly stimulate the proliferation and invasiveness of breast cancer cells in the autocrine and paracrine manners [19]. High CXCL12 levels in the tumor attract CXCR4-positive inflammatory, vascular and stromal cells into the tumor mass, where they will eventually support the tumor growth by secreting growth factors, cytokines, chemokines, and pro-angiogenic factors [19,39]. In addition, CXCR4 positive cancer cells can be recruited to CXCL12-rich mesenchymal stroma niches. This recruitment mimics the homing of normal stem cells to the bone marrow [39,40], and cancer cells homed to bone marrow reside in a microenvironment that protects them in a CXCR4-dependent manner from chemotherapy [41]. In this study, we demonstrated that the overall survival rate of IHCC patients with high CXCR4 expression is significantly lower than those with low CXCR4 expression. Elevated CXCR4 expression is related to vascular invasion, 
lymph node metastasis, and the TNM stages. This is similar to previous reports that CXCR4 may be a useful marker for cancer progression $[6,42,43]$. We also found that CXCR4 shRNA not only significantly reduced the expression of CXCR4, but also notably decreased phosphorylation of CXCR4 at serine 339. Considering the findings that the phosphorylation of CXCR4 at serine 339 may be a way to activate CXCR4 on the cells [44], our data further confirmed that CXCR4 shRNA could effectively inhibit CXCR4 function in IHCC cancers.

Tumorigenesis is the result of cell cycle disorganization, leading to uncontrolled cell proliferation and cancer progression. In this study, we have demonstrated that the blockade of CXCR4 can decrease IHCC cancer cell growth and cell cycle by prolonging the G0-G1 cycle and reducing the G2 and S phases, and inhibit tumorigenesis both in vitro and in vivo. The $\mathrm{Wnt} / \beta$-catenin pathway plays a major role in intrahepatic cholangiocarcinoma cell growth, metastasis, and cancer susceptibility [4,28-31]. Dysregulation of $\beta$-catenin and other Wnt components leads to activation of Wnt target genes, including c-myc, cyclin D1, and MMP-9 [45-47], and the enhancement of tumor formation [48]. Our data showed the TOPflash luciferase activity was sharply decreased by the inhibition of CXCR4 whereas FOPflash luciferase activity was nearly unchanged in the $\beta$-catenin/Tcf assay. Moreover, the expression of Wnt target genes, including $\beta$-catenin, c-myc, and MMP9, was markedly decreased, suggesting that the TCFbinding activity could be effectively inhibited by CXCR4 knockdown, which may suppress theWnt/ $\beta$-catenin signaling and Wnt target genes expression.

Next, we analyzed the expression of invasion-related genes Vimentin and Slug. These two genes are typical mesenchymal markers associated with the EMT process, which may influence carcinoma metastasis [49-54]. Our data showed that Vimentin and Slug were downregulated in CXCR4 knockdown cells, together with the decreased ability of invasion and migration as shown in transwell and wound healing assays. This is consistent with the previous report that CXCR4 could influence EMT formation and cancer invasion [31,55-60]. However, an intriguing phenomenon was also observed in the clinical trial of plerixafor (a CXCR4 inhibitor) as a combined treatment with intensive chemotherapy in heavily pre-treated relapse AML patients [61]. In the phase II study of 46 patients, a two-fold mobilization in leukemic blasts into the peripheral circulation was found, which was in modest correlation with CXCR4 expression. Furthermore, in a recent phase I study of another CXCR4 inhibitor LY2510924 for advanced cancer [62], the circulating tumor cell (CTC) counts were included as one of the study endpoints in addition to safety, pharmacokinetics, efficacy, and pharmacodynamics. In some (7/42) patients the CTC numbers were increased after the treatment with the CXCR4 inhibitor. Although the significance of these studies are inconclusive due to small sample sizes, these intriguing observations should prompt to investigate the mobilizing effects of CXCR4 inhibition in tumors in more details.

\section{Conclusions}

In conclusion, the present study has shown that high CXCR4 expression is associated with metastasis and a poor clinical outcome of IHCC. CXCR4 appears to influence IHCC cell phenotype via the canonical Wnt pathway. Future in vivo studies will be conducted with clinical available CXCR4 inhibitors like AMD3100 or LY2510924, and data from these experiments could result in faster changes of treatment for patients with IHCC.

\section{Abbreviations}

CXCR4: CXC chemokine receptor type 4; CXCL12: CXC chemokine ligand-12; shRNA: Short hairpin RNA; IHCC: Intrahepatic cholangiocarcinoma; EMT: Epithelial-to-mesenchymal transition; CTC: Circulating tumor cell.

\section{Competing interests}

The authors declare that they have no competing interests.

\section{Authors' contributions}

SZ and CQ conceived and designed the experiments. SZ and JW performed the experiments. SZ and CQ analyzed the data. SZ and JW performed the statistical analysis. SZ and CQ wrote the manuscript. All authors read and approved the final manuscript.

\section{Acknowledgments}

The authors thank Peter Liu and Mingze Ma for their lingual help. This work was supported by the grant from the Shandong Science and Technology Committee of China (2013GG3202192). The funder had no role in study design, data collection and analysis, decision to publish, or preparation of the manuscript.

Received: 16 September 2014 Accepted: 21 November 2014

Published online: 04 December 2014

\section{References}

1. Higashi M, Yamada N, Yokoyama S, Kitamoto S, Tabata K, Koriyama C, Batra SK, Yonezawa S: Pathobiological implications of MUC16/CA125 expression in intrahepatic cholangiocarcinoma-mass forming type. Pathobiology 2012, 79:101-106.

2. Okuda K, Nakanuma Y, Miyazaki M: Cholangiocarcinoma: recent progress. Part 2: molecular pathology and treatment. J Gastroenterol Hepatol 2002, 17:1056-1063

3. Okuda K, Nakanuma Y, Miyazaki M: Cholangiocarcinoma: recent progress. Part 1: epidemiology and etiology. J Gastroenterol Hepatol 2002, 17:1049-1055.

4. Leelawat K, Keeratichamroen S, Leelawat S, Tohtong R: CD24 induces the invasion of cholangiocarcinoma cells by upregulating CXCR4 and increasing the phosphorylation of ERK1/2. Oncol Lett 2013, 6:1439-1446.

5. Li X, Ma Q, Xu Q, Liu H, Lei J, Duan W, Bhat K, Wang F, Wu E, Wang Z: SDF-1/CXCR4 signaling induces pancreatic cancer cell invasion and epithelial-mesenchymal transition in vitro through non-canonical activation of Hedgehog pathway. Cancer Lett 2012, 322:169-176.

6. Holland JD, Gyorffy B, Vogel R, Eckert K, Valenti G, Fang L, Lohneis P, Elezkurtaj S, Ziebold U, Birchmeier W: Combined Wnt/beta-catenin, Met, and CXCL12/CXCR4 signals characterize basal breast cancer and predict disease outcome. Cell Rep 2013, 5:1214-1227.

7. Caruz A, Samsom M, Alonso JM, Alcami J, Baleux F, Virelizier JL, Parmentier M, Arenzana-Seisdedos F: Genomic organization and promoter characterization of human CXCR4 gene. FEBS Lett 1998, 426:271-278. 
8. Feng Y, Broder CC, Kennedy PE, Berger EA: HIV-1 entry cofactor: functional CDNA cloning of a seven-transmembrane, $G$ protein-coupled receptor. Science 1996, 272:872-877.

9. Ruffini PA, Morandi P, Cabioglu N, Altundag K, Cristofanilli M: Manipulating the chemokine-chemokine receptor network to treat cancer. Cancer 2007, 109:2392-2404.

10. Balkwill F: Cancer and the chemokine network. Nat Rev Cancer 2004, 4:540-550.

11. Burger JA, Kipps TJ: CXCR4: a key receptor in the crosstalk between tumor cells and their microenvironment. Blood 2006, 107:1761-1767.

12. Domanska UM, Kruizinga RC, Nagengast WB, Timmer-Bosscha H, Huls G, de Vries EG, Walenkamp AM: A review on CXCR4/CXCL12 axis in oncology: no place to hide. Eur J Cancer 2013, 49:219-230.

13. Hall JM, Korach KS: Stromal cell-derived factor 1, a novel target of estrogen receptor action, mediates the mitogenic effects of estradiol in ovarian and breast cancer cells. Mol Endocrinol 2003, 17:792-803.

14. Taichman RS, Cooper C, Keller ET, Pienta KJ, Taichman NS, McCauley LK: Use of the stromal cell-derived factor-1/CXCR4 pathway in prostate cancer metastasis to bone. Cancer Res 2002, 62:1832-1837.

15. Kaifi JT, Yekebas EF, Schurr P, Obonyo D, Wachowiak R, Busch P, Heinecke A, Pantel K, Izbicki JR: Tumor-cell homing to lymph nodes and bone marrow and CXCR4 expression in esophageal cancer. J Natl Cancer Inst 2005 97:1840-1847.

16. Kim SY, Lee CH, Midura BV, Yeung C, Mendoza A, Hong SH, Ren L, Wong D, Korz W, Merzouk A, Salari H, Zhang H, Hwang ST, Khanna C, Helman LJ: Inhibition of the CXCR4/CXCL12 chemokine pathway reduces the development of murine pulmonary metastases. Clin Exp Metastasis 2008, 25:201-211.

17. Sun J, Feng C, Liao W, Zhang H, Tang S: Expression of CXC chemokine receptor-4 and forkhead box 3 in neuroblastoma cells and response to chemotherapy. Oncol Lett 2014, 7:2083-2088.

18. Crane IJ, Wallace CA, McKillop-Smith S, Forrester JV: CXCR4 receptor expression on human retinal pigment epithelial cells from the blood-retina barrier leads to chemokine secretion and migration in response to stromal cell-derived factor 1 alpha. J Immunol 2000, 165:4372-4378.

19. Orimo A, Gupta PB, Sgroi DC, Arenzana-Seisdedos F, Delaunay T, Naeem R, Carey VJ, Richardson AL, Weinberg RA: Stromal fibroblasts present in invasive human breast carcinomas promote tumor growth and angiogenesis through elevated SDF-1/CXCL12 secretion. Cell 2005, 121:335-348.

20. Burger JA, Peled A: CXCR4 antagonists: targeting the microenvironment in leukemia and other cancers. Leukemia 2009, 23:43-52.

21. Muller A, Homey B, Soto H, Ge N, Catron D, Buchanan ME, McClanahan T, Murphy E, Yuan W, Wagner SN, Barrera JL, Mohar A, Verastegui E, Zlotnik A: Involvement of chemokine receptors in breast cancer metastasis. Nature 2001, 410:50-56.

22. Yu T, Liu K, Wu Y, Fan J, Chen J, Li C, Yang Q, Wang Z: MicroRNA-9 inhibits the proliferation of oral squamous cell carcinoma cells by suppressing expression of CXCR4 via the Wnt/beta-catenin signaling pathway. Oncogene 2014, 33:5017-5027.

23. Wang Z, Ma Q, Liu Q, Yu H, Zhao L, Shen S, Yao J: Blockade of SDF-1/ CXCR4 signalling inhibits pancreatic cancer progression in vitro via inactivation of canonical Wnt pathway. Br J Cancer 2008, 99(10):1695-1703.

24. Yu T, Liu K, Wu Y, Fan J, Chen J, Li C, Yang Q, Wang Z: MicroRNA-9 inhibits the proliferation of oral squamous cell carcinoma cells by suppressing expression of CXCR4 via the Wnt/beta-catenin signaling pathway. Oncogene 2014, 33:5017-5027.

25. Hu TH, Yao Y, Yu S, Han LL, Wang WJ, Guo H, Tian T, Ruan ZP, Kang XM, Wang J, Wang SH, Nan KJ: SDF-1/CXCR4 promotes epithelialmesenchymal transition and progression of colorectal cancer by activation of the Wnt/beta-catenin signaling pathway. Cancer Lett 2014, 354:417-426.

26. Wang J, Cai J, Han F, Yang C, Tong Q, Cao T, Wu L, Wang Z: Silencing of CXCR4 blocks progression of ovarian cancer and depresses canonical Wnt signaling pathway. Int J Gynecol Cancer 2011, 21:981-987.

27. Tamura M, Sato MM, Nashimoto M: Regulation of CXCL12 expression by canonical Wnt signaling in bone marrow stromal cells. Int J Biochem Cell Biol 2011, 43:760-767.

28. Ohira S, Sasaki M, Harada K, Sato Y, Zen Y, Isse K, Kozaka K, Ishikawa A, Oda $K$, Nimura $Y$, Nakanuma $Y$ : Possible regulation of migration of intrahepatic cholangiocarcinoma cells by interaction of CXCR4 expressed in carcinoma cells with tumor necrosis factor-alpha and stromal-derived factor-1 released in stroma. Am J Pathol 2006, 168:1155-1168.

29. Gentilini A, Rombouts K, Galastri S, Caligiuri A, Mingarelli E, Mello T, Marra F, Mantero S, Roncalli M, Invernizzi P, Pinzani M: Role of the stromal-derived factor-1 (SDF-1)-CXCR4 axis in the interaction between hepatic stellate cells and cholangiocarcinoma. J Hepatol 2012, 57:813-820.

30. Tan XY, Chang S, Liu W, Tang HH: Silencing of CXCR4 inhibits tumor cell proliferation and neural invasion in human hilar cholangiocarcinoma. Gut Liver 2014, 8:196-204.

31. Okamoto K, Tajima H, Nakanuma S, Sakai S, Makino I, Kinoshita J, Hayashi H, Nakamura K, Oyama K, Nakagawara H, Fujita H, Takamura H, Ninomiya I, Kitagawa H, Fushida S, Fujimura T, Harada S, Wakayama T, Iseki S, Ohta T: Angiotensin II enhances epithelial-to-mesenchymal transition through the interaction between activated hepatic stellate cells and the stromal cell-derived factor-1/CXCR4 axis in intrahepatic cholangiocarcinoma. Int J Oncol 2012, 41:573-582.

32. Zhao S, Zhou L, Niu G, Li Y, Zhao D, Zeng H: Differential regulation of orphan nuclear receptor TR3 transcript variants by novel vascular growth factor signaling pathways. FASEB J 2014, 28:4524-4533.

33. Rubin JB, Kung AL, Klein RS, Chan JA, Sun Y, Schmidt K, Kieran MW, Luster $A D$, Segal RA: A small-molecule antagonist of CXCR4 inhibits intracranial growth of primary brain tumors. Proc Natl Acad Sci U S A 2003, 100:13513-13518.

34. Smith MC, Luker KE, Garbow JR, Prior JL, Jackson E, Piwnica-Worms D, Luker GD: CXCR4 regulates growth of both primary and metastatic breast cancer. Cancer Res 2004, 64:8604-8612.

35. De Falco V, Guarino V, Avilla E, Castellone MD, Salerno P, Salvatore G, Faviana P, Basolo F, Santoro M, Melillo RM: Biological role and potential therapeutic targeting of the chemokine receptor CXCR4 in undifferentiated thyroid cancer. Cancer Res 2007, 67:11821-11829.

36. Porvasnik S, Sakamoto N, Kusmartsev S, Eruslanov E, Kim WJ, Cao W, Urbanek C, Wong D, Goodison S, Rosser CJ: Effects of CXCR4 antagonist CTCE-9908 on prostate tumor growth. Prostate 2009, 69:1460-1469.

37. Hassan S, Buchanan M, Jahan K, Aguilar-Mahecha A, Gaboury L, Muller WJ, Alsawafi Y, Mourskaia AA, Siegel PM, Salvucci O, Basik M: CXCR4 peptide antagonist inhibits primary breast tumor growth, metastasis and enhances the efficacy of anti-VEGF treatment or docetaxel in a transgenic mouse model. Int J Cancer 2011, 129:225-232.

38. Zeelenberg IS, Ruuls-Van Stalle L, Roos E: The chemokine receptor CXCR4 is required for outgrowth of colon carcinoma micrometastases. Cancer Res 2003, 63:3833-3839.

39. Olumi AF, Grossfeld GD, Hayward SW, Carroll PR, Tlsty TD, Cunha GR: Carcinoma-associated fibroblasts direct tumor progression of initiated human prostatic epithelium. Cancer Res 1999, 59:5002-5011.

40. Konopleva MY, Jordan CT: Leukemia stem cells and microenvironment: biology and therapeutic targeting. J Clin Oncol 2011, 29:591-599.

41. Nervi B, Ramirez P, Rettig MP, Uy GL, Holt MS, Ritchey JK, Prior JL, Piwnica-Worms D, Bridger G, Ley TJ, DiPersio JF: Chemosensitization of acute myeloid leukemia (AML) following mobilization by the CXCR4 antagonist AMD3100. Blood 2009, 113:6206-6214.

42. Zhang Z, Ni C, Chen W, Wu P, Wang Z, Yin J, Huang J, Qiu F: Expression of CXCR4 and breast cancer prognosis: a systematic review and meta-analysis. BMC Cancer 2014, 14:49.

43. Liu CF, Liu SY, Min XY, Ji YY, Wang N, Liu D, Ma N, Li ZF, Li K: The prognostic value of CXCR4 in ovarian cancer: a meta-analysis. PLoS One 2014, 9:e92629.

44. Woerner BM, Warrington NM, Kung AL, Perry A, Rubin JB: Widespread CXCR4 activation in astrocytomas revealed by phospho-CXCR4-specific antibodies. Cancer Res 2005, 65:11392-11399.

45. Chang B, Kim J, Jeong D, Jeong Y, Jeon S, Jung SI, Yang Y, Kim Kl, Lim JS, Kim C, Lee MS: Klotho inhibits the capacity of cell migration and invasion in cervical cancer. Oncol Rep 2012, 28:1022-1028.

46. Huang CL, Liu D, Ishikawa S, Nakashima T, Nakashima N, Yokomise H, Kadota K, Ueno M: Wnt1 overexpression promotes tumour progression in non-small cell lung cancer. Eur J Cancer 2008, 44:2680-2688.

47. Doucas H, Garcea G, Neal CP, Manson MM, Berry DP: Changes in the Wnt signalling pathway in gastrointestinal cancers and their prognostic significance. Eur J Cancer 2005, 41:365-379.

48. Kolligs FT, Bommer G, Goke B: Wnt/beta-catenin/tcf signaling: a critical pathway in gastrointestinal tumorigenesis. Digestion 2002, 66:131-144. 
49. Thiery JP: Epithelial-mesenchymal transitions in tumour progression. Nat Rev Cancer 2002, 2:442-454.

50. Shioiri M, Shida T, Koda K, Oda K, Seike K, Nishimura M, Takano S, Miyazaki M: Slug expression is an independent prognostic parameter for poor survival in colorectal carcinoma patients. Br J Cancer 2006, 94:1816-1822.

51. Tsubaki M, Komai M, Fujimoto S, Itoh T, Imano M, Sakamoto K, Shimaoka H, Takeda T, Ogawa N, Mashimo K, Fujiwara D, Mukai J, Sakaguchi K, Satou T, Nishida S: Activation of NF-kappaB by the RANKL/RANK system upregulates snail and twist expressions and induces epithelial-tomesenchymal transition in mammary tumor cell lines. J Exp Clin Cancer Res 2013, 32:62.

52. Zhu L, Qin H, Li PY, Xu SN, Pang HF, Zhao HZ, Li DM, Zhao Q: Response gene to complement-32 enhances metastatic phenotype by mediating transforming growth factor beta-induced epithelial-mesenchymal transition in human pancreatic cancer cell line BxPC-3.J Exp Clin Cancer Res 2012, 31:29.

53. Kaufhold S, Bonavida B: Central role of Snail1 in the regulation of EMT and resistance in cancer: a target for therapeutic intervention. J Exp Clin Cancer Res 2014, 33:62.

54. Li M, Zhang B, Sun B, Wang X, Ban X, Sun T, Liu Z, Zhao X: A novel function for vimentin: the potential biomarker for predicting melanoma hematogenous metastasis. J Exp Clin Cancer Res 2010, 29:109.

55. Sobolik T, Su YJ, Wells S, Ayers GD, Cook RS, Richmond A: CXCR4 drives the metastatic phenotype in breast cancer through induction of CXCR2 and activation of MEK and PI3K pathways. Mol Biol Cell 2014, 25:566-582.

56. Zhang SS, Han ZP, Jing YY, Tao SF, Li TJ, Wang H, Wang Y, Li R, Yang Y, Zhao X, Xu XD, Yu ED, Rui YC, Liu HJ, Zhang L, Wei LX: CD133(+)CXCR4(+) colon cancer cells exhibit metastatic potential and predict poor prognosis of patients. BMC Med 2012, 10:85.

57. Fanelli MF, Chinen LT, Begnami MD, Costa WL Jr, Fregnami JH, Soares FA, Montagnini AL: The influence of transforming growth factor-alpha, cyclooxygenase-2, matrix metalloproteinase (MMP)-7, MMP-9 and CXCR4 proteins involved in epithelial-mesenchymal transition on overall survival of patients with gastric cancer. Histopathology 2012, 61:153-161.

58. Bertran E, Caja L, Navarro E, Sancho P, Mainez J, Murillo MM, Vinyals A, Fabra $A$, Fabregat I: Role of CXCR4/SDF-1 alpha in the migratory phenotype of hepatoma cells that have undergone epithelial-mesenchymal transition in response to the transforming growth factor-beta. Cell Signal 2009, 21:1595-1606

59. Taki M, Higashikawa K, Yoneda S, Ono S, Shigeishi H, Nagayama M, Kamata $\mathrm{N}$ : Up-regulation of stromal cell-derived factor-1alpha and its receptor CXCR4 expression accompanied with epithelial-mesenchymal transition in human oral squamous cell carcinoma. Oncol Rep 2008, 19:993-998.

60. Onoue T, Uchida D, Begum NM, Tomizuka Y, Yoshida H, Sato M: Epithelialmesenchymal transition induced by the stromal cell-derived factor-1/ CXCR4 system in oral squamous cell carcinoma cells. Int J Oncol 2006, 29:1133-1138.

61. Uy GL, Rettig MP, Motabi IH, McFarland K, Trinkaus KM, Hladnik LM, Kulkarni S, Abboud CN, Cashen AF, Stockerl-Goldstein KE, Vij R, Westervelt P, DiPersio JF: A phase 1/2 study of chemosensitization with the CXCR4 antagonist plerixafor in relapsed or refractory acute myeloid leukemia. Blood 2012, 119:3917-3924.

62. Galsky MD, Vogelzang NJ, Conkling P, Raddad E, Polzer J, Roberson S, Stille JR, Saleh M, Thornton D: A Phase I Trial of LY2510924, a CXCR4 Peptide Antagonist, in Patients with Advanced Cancer. Clin Cancer Res 2014, 20(13):3581-3588.

doi:10.1186/s13046-014-0103-8

Cite this article as: Zhao et al:: Blockade of CXCL12/CXCR4 signaling inhibits intrahepatic cholangiocarcinoma progression and metastasis via inactivation of canonical Wnt pathway. Journal of Experimental \& Clinical Cancer Research 2014 33:103.

\section{Submit your next manuscript to BioMed Central and take full advantage of:}

- Convenient online submission

- Thorough peer review

- No space constraints or color figure charges

- Immediate publication on acceptance

- Inclusion in PubMed, CAS, Scopus and Google Scholar

- Research which is freely available for redistribution 